\title{
Strengthening the Roles of Parent Teacher Association in Secondary Schools for Better Community Participation in Educational Development in Nigeria
}

\author{
Haastrup Timilehin Ekundayo ${ }^{1} \&$ Hezekiah Ogbomida Alonge $^{2}$ \\ ${ }^{1}$ Department of Educational Foundations and Management, Ekiti State University, Ado-Ekiti, Nigeria \\ ${ }^{2}$ Department of Educational Studies and Management, University of Benin, Benin-City, Nigeria \\ Correspondence: Haastrup Timilehin Ekundayo, Department of Educational Foundations and Management, \\ Faculty of Education, Ekiti State University, Ado-Ekiti, Nigeria. Tel: 234-803-220-2792. E-mail: \\ haastrupt2006@yahoo.com
}

\author{
Received: March 9, $2012 \quad$ Accepted: April 16, $2012 \quad$ Online Published: August 3, 2012 \\ doi:10.5539/jedp.v2n2p16 URL: http://dx.doi.org/10.5539/jedp.v2n2p16
}

\begin{abstract}
The paper examined the traditional roles of the Parent Teacher Association (PTA) in secondary schools in Nigeria. The state of secondary schools in Nigeria suggests that there are still some problems facing the school in which the PTA had been found wanting. These include inadequate financial support of the PTA to the schools; lack of cooperation between the schools and the parents; inadequate supervision of schools among others. The paper therefore made some recommendations on how the roles of the PTA can be strengthened for better community participation in the provision of qualitative education at the secondary school level. These include giving the PTA more involvement in educational financing; giving them more responsibilities in school administration; giving them direct labour for execution of school projects instead of giving to outside contractors.
\end{abstract}

Keywords: parent teacher association, community participation, secondary schools, educational development

\section{Introduction}

The first generation of secondary schools in Nigeria was established and administered by the missionary bodies with the first secondary school established in 1859 by the Church Missionary Society (CMS). The first government secondary school, King's College, was established in 1899 (Adesina, 1984). According to Ajayi (1999), government's participation in administration of secondary schools increased considerably in 1903 when a department of education was established for the administration of education in the country. The author posited that over the years, Nigerian governments have been playing a dominant role in secondary school administration particularly in the areas of funding, provision of facilities, supervision, maintenance of standard among others.

Abdullahi (1996) argued that in the 1960s when schools were not many in Nigeria, governments were able to effectively fund education and only few Parent teacher Associations (PTAs) existed. However, with the advent of numerous problems in the education sector, it became necessary for most of the schools to have PTAs to assist in solving the problems of the schools.

Parent teacher Association is a democratic organization which attempts to bring parents and teachers together in the interest of the child (Ajayi, 1999). It is a formal link of communication on school matters between the teachers and parents. According to Oniyangi (2008), the meeting of this body serves as a forum for the exchange of ideas between teachers and parents about school programmes towards the smooth running of the school and the achievements of the goals of the school.

Abdullahi (1996) highlighted some aims and objectives the national PTA of Nigeria to include provision of platform for parents, guardians, sponsors, and teachers of students of Nigerian primary, secondary and tertiary educational institutions to meet, exchange views deeply, analyse issues, make recommendations, take and effectively pursue implementation of decisions on matters affecting education in Nigeria with appropriate agencies. Cooperating with and support morally and financially various governments and agencies of education to achieve high standard of academic performance, discipline, morality, service and integrity in Nigerian schools. 
Besides, the author still argued that the PTA fosters mutual understanding, harmonious relationship and cooperation among parents, guardians, sponsors, and teachers in the fulfillment of the common goals of the school as well as ensures a suitable, uniform and high standard of discipline, both at home and at school among others.

There is no doubt that the performance of these roles will enhance better performance of the school system. However, it appears that the secondary schools are still facing a myriad of problems in the country.

\section{Some Roles of the PTA in Educational Development}

Nwakwo (1983) posited that the task of school administration include planning and policy making, provision and maintenance of fund and facilities, improvement of instructional programmes and maintenance of school-community relationships. Some researchers have submitted in their various studies that the PTA has however been performing in some of these areas as seen hereunder:

Owuamanam (1991) submitted that most Nigerian communities make financial contributions through the PTA levy and personal donations for the support of the schools in the communities. The author also submitted that communities participate in school administration by electing their members to the Board of Governors.

In another dimension, Abdullahi (1996) also posited that the PTA enhance understanding and good rapport between the teachers and parents; lobby government for support in the schools; and curtail crises that often arise in the schools.

Oniyangi (2008) also agreed that the PTA assists in improving the enrolment of the schools in their communities; helps in maintaining disciplines in the schools; ensure smooth co-existence, understanding and cooperation between the school and the community. Adewumi in Oniyangi (2008) also submitted that the PTA helps in sensitisation and mobilisation of parents on enrolment attendance and retention of their children or wards in schools. Besides, Abdullahi (1996) also reported that the PTA complements governments' efforts in the provision and maintenance of infrastructures in the schools.

These and many more suggest that the PTA has been participating on matter affecting education in Nigeria. It is to be noted however, that virtually all the secondary schools in the country has the PTA in place. Despite the laudable roles of the PTA in secondary schools it appears that the problems of the schools still thrive. It therefore presupposes that the roles of the PTA can be strengthened in order to enhance better community participation in the schools.

\section{Problems of PTA in School Administration}

The effective administration of secondary schools could be hampered where the PTA is not performing its roles as expected. A careful examination of the secondary school system in Nigeria suggests that there are some problems bedeviling the PTA which have been hindering effective and smooth relationship between the association and the schools. Some of these are examined as follows:

Inadequate funding: Inadequate funding is a major problem facing the educational institutions in Nigeria from the primary level to the university level. Aghenta (1984) remarked that the success of any secondary school system depends on the amount of resources available to it. Money is an input of any educational system that provides the essential purchasing power with which the system acquires its human and physical inputs (Adepoju, 2002). The author further argued that with little supply of money, education becomes helpless, while with ample supply, its problems become manageable even though they do not vanish. However, Ajayi (1999) observed that the major problem that compounds schools' financial inadequacy is irregular payment of school fees and PTA levy; and inadequate financial support of the PTA. It is believed that money generated through this medium would help complement governments' effort in the provision of fund for secondary schools.

Inadequate facilities: The challenges of physical and instructional facilities seem to hinder effective performance of the schools (Adedeji, 1998). Efficient and effective running of schools to achieve pre-determined goals can hardly be without sufficient facilities to aid teaching and learning. Meanwhile, the state of inadequacy of facilities in most secondary schools in Nigeria is a manifestation of poor funding of the system.

Lack of cooperation between the school authority and the parents: It has been observed that some school principals do not involve the parents in administration of the schools for the fear of being criticized. Fehrman, Keith and Reiners (1987) argued that most parents would like to play a more active role in their students' progress in schools and decision making about school programmers but school administrators/ principals and teachers exhibit a great reluctance to encourage parents to become partners in governance. The non-involvement of parents in school governance, most often than not, results in lack of cooperation between the school and the 
parents which invariably limits the extent to which the schools can perform.

Poor supervision of schools: It has been argued that schools are not well-supervised by the agents involved (Abiodun-Oyebanji, 2004). Ayodele (2002) categorized the supervisors of schools into: (i) internal supervisors - the within - the school supervisors such as principals, vice-principals and heads of departments; (ii) external supervisors - the outside - the school supervisors in which the PTA is part. The primary responsibility of the supervisors is to see that schools are run in accordance with the laid down regulations. The negligence of this area of responsibility seems to hinder effective teaching-learning activities in the secondary schools.

Poor academic performance: According to Ajayi and Ekundayo (2010), one of the major obstacles to the development of secondary education in Nigeria is the persistent mass failure of students in public examinations. Some of the reasons adduced for this poor performance include lack of proper guidance by parents; failure of parents to provide necessary materials for their children; parents aiding examination malpractices among others.

The above are some of the problems bedeviling the secondary school system in which the PTA has been found wanting. This appears to be a reason why many Nigerians are turning to private schools as alternatives to the failing public schools.

\section{Strategies for Strengthening the Roles of the PTA}

The following are some of the ways through which the roles of the PTA can be strengthened towards better service delivery in the schools:

More involvement of PTA in education financing: In order to enhance parents' participation in educational financing in secondary schools, members of the PTA should be made members of boards and committees that relate to rising and spending of funds in the schools. There are several levies which are collected in the schools (such as PTA levy, lesson fee, among others) in which members of the PTA can be part of the spending team. The need for probity and efficient utilization of the schools' resources will make parents be willing to give more financial assistance to schools.

More involvement of PTA in school administration: Opportunities should be given to members of the PTA to take part in decision making about school programmers. This may include being a school board member, participation on parent's advisory committee. Areas in which parents may be helping to make programmed decisions include goal setting, development and implementation of programmed activities and fund allocations. Hicks (1992), Sammons, Hillman and Mortimore (1995) and Cotton and Wikelund (2001) submitted in their various studies that many benefits are accrued for the school system and for parents themselves when parents become involved in the school activities.

Involving parents in organized school events: In order to create a better mutual understanding and closer links between the school and the community, members of the community as well as members of the PTA should be involved in organized school events such as sports and other school activities. Oniyangi (2008) submitted that the school should make itself not only accessible to the community when community development activities are organized but also participate fully whenever called upon to do so. Local arts and crafts can be taught in schools but learning becomes more profitable when such local experts are involved in the training of the skills to the young ones.

Giving direct labour for execution of projects: Members of the community as well as members of the PTA who are experts in one profession or the other (such as bricklayers, carpenters, plumbers, electricians, among others) should be encouraged to take up contracts in the building of schools when these are to be done. Akintelure (2007) suggested that if the construction of physical facilities in schools are awarded to members of the PTA instead of contractors, parents would be willing to make additional sacrifice in the development of the schools.

\section{Conclusion and Recommendations}

Secondary schools can only produce good results if there is effective and efficient management of the human and material resources in the system. It is concluded in this paper that the PTA has been performing some roles in the schools; enhancing good relationship between the school and the community; maintenance of discipline in the schools; and mobilizing parents on enrolment, attendance and retention of their children and wards in schools.

However, the paper still concluded that there are still some problems of the PTA in the administration of schools which include inadequate financial support of the PTA to the schools, lack of cooperation between the schools authority and the parents, inadequate supervision of schools, parents aiding and abetting examination malpractices which invariably culminates into poor performance of students in public examinations.

Based on these findings, recommendations were made on how to strengthen the roles of the PTA in order to 
expect better community participation in the development of secondary schools. These include giving members of the PTA more involvement in educational financing; involving them the more in school administration; giving them direct labour for execution of projects instead of giving to outside contractors.

\section{References}

Abdullahi, S. U. (1996). Parent teacher association as an instrument of community participation in education. Retrieved from http://www. zedang.org/agmlectures/ $/ 4^{\text {th }} \cdot$.pdf on 31/03/2010.

Abiodun-Oyebanji, O. (2004). The principals' supervisory practices and teachers' job performance in Ekiti State secondary schools. Journal of Contemporary Issues in Education, 2(1), 223-230.

Adedeji, S. O. (1998). The relationship between resource utilisation and academic performance in vocational education in Osun State secondary schools. An unpublished Ph.D. Thesis, submitted to the University of Ibadan, Ibadan, Nigeria.

Adepoju, T. L. (2002). Quality control of UBE in Nigeria: policy options. In T. Ajayi, J. O. Fadipe, P. K. Ojedele and E. E. Oluchukwu (eds), Planning and administration for UBE in Nigeria (pp. 351-360). NIEPA Publications.

Adesina, S. (1984). Landmarks in secondary education in Nigeria. In S. Adesina and S. Ogunsaju (eds), Secondary Education in Nigeria (pp. 1-15). Ile-Ife: University of Ife Press Ltd.

Aghenta, J. A. (1984). Towards a system approach to the planning of secondary education in Nigeria. In S. Adesina and S. Ogunsaju (eds.), Secondary Education in Nigeria (pp. 227-243). Ile-Ife: University of Ife Press Ltd.

Ajayi, I. A. (1999). Teachers' assessment of the role of PTA in administration of secondary schools. Journal of Education Research and Evaluation, 3(2), 110-116.

Ajayi, I. A., \& Ekundayo, H. T. (2010). Contemporary Issues in Educational Management. Lagos: Bolabay Publications.

Akintelure, H. (2007). The challenges and roles of parents in ensuring the success of the secondary education sector agenda of the national economic empowerment and development strategies (NEEDS). In P. N. C. Ngwu (ed.), The Principal and Education Reforms in Nigeria (pp. 218-225). A publication of the All Nigerian Conference of Principals of Secondary Schools.

Ayodele, J. B. (2002). The perception of secondary school teachers on the impact of external supervision. Journal of Educational Foundations and Management, 2(1), 35-42.

Cotton, K., \& Wikelund, R. K. (2001). Parent involvement in education. Retrieved from http://www.nwrel.org/scpd/sirs/3/cu6html

Fehrman, P. G., Keith, T. Z., \& Reiners, T. M. (1987). Home influence on school learning: direct and indirect effects of parental involvement on high school grades. Journal of Educational Research, 80, 330-336.

Hicks, B. W. (1992). Parents', teachers' and students' perception of effective principals in selected middle schools in South Carolina. Dissertation Abstracts Internatinoal.

Nwakwo, J. I. (1982). Educational administration: theories and practice. New Delhi: Vikas Publishing House.

Oniyangi, S. A. (2008). Strategies for promoting school and community relationship for better productivity. In D. O. Durosaro, R. A. Shehu and K. Mohammed (eds.), Classroom management techniques for the newly recruited primary school teachers in Kwara State (pp. 99-110). A publication of Kwara State Universal Basic Education Board, Ilorin.

Owuamanam, D. O. (1991). Foundations of sociology and psychology of education. Lagos: Abimas Lithografiks Company.

Sammons, P.; Hillman, J., \& Mortimore, P. (1995). Key characteristics of effective schools. A Review of School Effectiveness Research. London: Institute of Education. 